\title{
Istilah Kekerabatan pada Bahasa Sangihe (Suatu Kajian Linguistik Antropologi)
}

\author{
Lidya Grace Lineke Patimbano \\ lidyaferon@gmail.com \\ Djeinnie Imbang \\ A. G. Senduk \\ Pascasarjana \\ Universitas Sam Ratulangi
}

\begin{abstract}
Language is a communication tool that has an important role to convey information. Languange is also a sound alert system that agreed to be used by members of certain communities work togather, communicate and identifying themselves. The background of this study by the term kinship tends to do with the concept of culture used by certain people who call someone in the family as in the community Sangihe. These factors that the attention of researchers to the term of kinship in the society. The purpose of this study is to indentify kinship term in the Sangihe Society and explain the meaning of kinship in the Sangihe sociey that reflect of culture.

The method used in this research is descriptive qualitative method. To obtain the data in the field. Burling theory (1970) to answer the first question and the theory Spradley (1979) and Casson (1981) to answer the second question. To obtain the data in the field, researchers used a method refer and method capable (SBCL) and using the questionnaire in the form of a questionnaire of Sudaryanto (1993) and interview techniques as recommended by Spradley (1997), which consists of general questions, specific questions, sample questions, questions based on experiences and questions native language or dialect. These data are then captured and recorded. In the data analysis methods, used analysis of the concept of expression to identify and explain the data as a whole, on the basis of linguistic theory of cultural anthropology discover the meaning behind the kinship terms on Sangihe society.
\end{abstract}

\section{Pendahuluan}

Bahasa adalah sarana komunikasi yang memiliki peran penting dalam menyampaikan suatu informasi. Bahasa juga merupakan sistem tanda bunyi yang disepakati untuk dipergunakan para anggota kelompok masyarakat tertentu dalam bekerja sama, berkomunikasi dan mengidentifikasikan diri (Kridalaksana, 2008:3). Bahasa sebagai sarana komunikasi, maka segala hal yang berkaitan dengan komunikasi tidak lepas dari bahasa, seperti memahami realitas, berpikir dan merasakan. Dengan kata lain, tanpa 
memiliki kemampuan berbahasa, seseorang tidak dapat melakukan kegiatan berpikir untuk menangkap dan mengerti terhadap sesuatu (Djojosuroto, 2007:45).

Menurut Koentjaraningrat (1990:160) kebudayaan dan bahasa mempunyai kerterkaitan yang signifikan dalam kehidupan manusia. Dikaitkan dengan kebudayaan, bahasa dipandang sebagai suatu alat terpenting bagi manusia dalam kehidupan sosial budaya, namun tidak terlepas dari unsur-unsur kebudayaan lainnya atau kesemuanya unsur kebudayaan saling mempengaruhi satu dengan lainnya.

Bahasa berkaitan erat dengan budaya yang meliputi kebiasaan, cara hidup, bergaul, bekerja dan sebagainya. Bahasa yang dimiliki masyarakat mempengaruhi masyarakat dalam memahami lingkungannya. Demikian juga sebaliknya, perkembangan bahasa dipengaruhi oleh budaya masyarakat penuturnya (Mulyanto, 2009:53). Selanjutnya Masinambow dalam Chaer dan Agustina (2004:165) menyebutkan bahasa dan kebudayaan merupakan dua sistem yang melekat pada manusia artinya kebudayaan itu adalah satu sistem yang mengatur interaksi manusia dalam masyarakat maka bahasa adalah suatu sistem yang berfungsi sebagai sarana berlangsung interaksi itu. Dengan kata lain hubungan yang erat itu berlaku sebagai kebudayaan merupakan sistem yang mengatur interaksi manusia, sedangkan bahasa merupakan sistem yang mempunyai fungsi sebagai sarana berlangsungnya interaksi tersebut.

Pemakaian bahasa daerah dapat menciptakan kehangatan dan keakraban. Oleh karenanya bahasa daerah diasosiasikan dengan perasaan, kehangatan, keakraban dan spontanitas (Alwasilah, 1993:176). Bahasa daerah adalah salah satu kekayaan budaya yang dimiliki oleh setiap suku bangsa dan merupakan warisan turun temurun yang tidak ternilai harganya (Walangarei, 2009:84).

Sebagai alat komunikasi, bahasa memegang peran penting dalam struktur masyarakat. Komunikasi menggunakan bahasa yang terjadi dalam suatu komunitas masyarakat membentuk ciri dan karakter budaya, sosial, ekonomi, dan aspek lainnya. Bahasa sesungguhnya mampu membentuk, mengarahkan, dan membimbing interaksi masyarakat dengan: sesamanya, lingkungan alamnya, dunia luarnya, dan hal-hal lain mengenai fenomena-fenomena yang tidak bisa dijelaskan dengan akal dan pikiran. Dengan demikian, bahasa merupakan salah satu unsur penting yang mempengaruhi dan 
membentuk karakter dan ciri spesifik suatu komunitas masyarakat yang dipakai oleh masyarakat tertentu yang menyebut seseorang dalam hubungan kekeluargaan

Istilah kekerabatan cenderung berkaitan dengan konsep budaya yang dipakai oleh masyarakat tertentu yang menyebut seseorang dalam hubungan kekeluargaan. Hubungan kekeluargaan dalam masyarakat ditandai dengan penggunaan kata-kata atau kosakata tertentu seperti ayah, ibu, sepupu, paman dan pengelompokannya menurut garis keturunan atau karena perkawinan.

Lounsbury (dalam Leech 1981) megemukakan istilah kekerabatan dapat dijelaskan melalui jenis kelamin, generasi dan garis keturunn. Ia mencontohkan kata ayah dan Paman untuk laki-laki sedangkan kata $I b u$ dan bibi untuk perempuan adalah kekerabatan berdasarkan jenis kelamin. Istiah kekerabatan berdasarkan generasi berdasarkan tiga kelompok, yaitu (1) generasi di atas ego (2) generasi di bawah ego, dan (3) generasi sejajar ego. Ego berarti diri sendiri. Garis keturunan ini dibagi dua, yaitu garis keturunan langsung dan sejajar. Keturunan langsung berhubungan dengan garis vertikal dalam pohon keluarga (contoh kakek dan nenek) sedangkan garis keturunan horizontal (contoh paman dan bibi).

Masyarakat Sangihe (Kabupaten Kepulauan Sangihe ) merupakan salah satu etnik di Propinsi Sulawesi Utara yang memiliki bahasa daerah dengan tutur yang cukup khas dan menonjol di antara etnik lain yang ada di Propinsi Sulawesi Utara. Masyarakat Sangihe, atau sering disebut "Orang Sanger" berasal dari bagian semenanjung paling utara dari Propinsi Sulawesi Utara. Masyarakat Sangihe adalah masyarakat kepulauan dengan nenek moyang sebagai pelaut.

Bahasa Sangihe tidak mempunyai aksara, oleh karenanya Suku Sangihe tidak mengenal sistem tulisan. Bangsa Eropa yang masuk ke Pulau Sangihe membawa perubahan bagi orang Sangihe dengan mengenalkan huruf Latin sebagai bentuk tulisan. Sejak saat itu orang Sangihe mulai mengenal tulisan.

Bahasa Sangihe tersebar selain di Kepulauan Sangihe sendiri, juga di bagian utara Pulau Sulawesi. Di Kepulauan Sangihe, bahasa Sangihe dapat ditemukan digunakan di Pulau Sangihe Besar dan pulau-pulau kecil di sekitarnya, Pulau Siau dan sekitarnya, Pulau Tagulandang dan sekitarnya dan pulau-pulau lain di perbatasan utara Indonesia. Di bagian utara Pulau Sulawesi, bahasa Sangihe digunakan di beberapa daerah sekitar Minahasa: Belang, Bantik, Manado Tua, Bunaken, Nain, Siladen, Mantehage, Gangga, Bangka, 
Talise, Likupang, Lembe, sebagian Bitung, dan di daerah kaki Gunung Klabat (H. Kern dalam Tata bahasa Sangihe, Decroly Juda,2004).

Menurut Bawole dalam Ratu (1981), bahasa Sangihe terbagi dalam 8 dialek, yaitu: (i) Tabukan, (ii) Tahuna, (iii) Kendahe, (iv) Kolongan, (v) Manganitu, (vi) Tamako, (vii) Siau, dan (viii) Tagulandang. Secara umum, 8 dialek tersebut dapat dikelompokkan menjadi 3 dialek menurut pulau-pulau besarnya, yaitu: (i) dialek Sangihe di Pulau Sangihe, (ii) dialek Siau di Pulau Siau, dan (iii) dialek Tagulandang di Pulau Tagulandang.

Melalui penelitian linguistik antropologi ini, dapat dijelaskan bagaimana istilahistilah kekerabatan dan makna budaya apa yang terkandung di dalamnya. Untuk menjawab fenomena tersebut, maka peneliti mengkaji jenis-jenis istilah kekerabatan bahasa Sangihe dari tinjauan linguistic antropologi melalui aspek kebahasaan itu terkandung makna budaya untuk mempererat hubungan keakraban,kekerabatan, kekeluargaan sebagai suatu budaya berbahasa, yang sekaligus merupakan ciri-ciri bahasa Sangihe saat ini.

Peneliti tertarik untuk mengkaji Istilah kekerabatan bermakna budaya dalam bahasa Sangihe misalnya dalam masyarakat Sangihe mengenal istilah yang berbeda untuk anak pertama 'akang', anak ke dua 'ara', anak ke tiga 'ari', anak yang terakhir 'embo'. Hal ini yang memberi motivasi kepada peneliti untuk melakukan penelitian pada masyarakat Sangihe.

\section{Perumusan Masalah}

Berdasarkan latar belakang permasalahan di atas, maka berikut ini adalah masalah yang dapat dirumuskan, yaitu:

1. Apa saja istilah-istilah kekerabatan bahasa Sangihe?

2. Makna budaya apa yang tersirat/terkandung di dalam istilah-istilah kekerabatan bahasa Sangihe?

\section{Tujuan Penelitian}

Berdasarkan perumusan masalah di atas, maka penelitian ini bertujuan untuk:

1. Mengidentifikasi istilah-istilah kekerabatan bahasa Sangihe. 
2. Menjelaskan makna budaya apa yang terkandung dalam istilah-istilah kekerabatan bahasa Sangihe

\section{Kerangka Teoretis}

Landasan teori yang penulis gunakan dalam penelitian ini, yaitu sebagai berikut:

\section{Linguistik Antropologi}

Secara umum penelitian ini dikaji berdasarkan aspek linguistik dan aspek budaya menurut Kridalaksana (2001) disebut dengan linguistik antropologi, yaitu memandang bahasa melalui konsep inti antropologi. Mengutip pendapat Hymes, Duranti (1997:2) menyatakan bahwa linguistik antropologi mengkaji ujaran bahasa dalam konteks antropologi. Pendekatan dalam penelitian kebudayaan mengacu pada berbeda bahasa berarti berbeda budaya. Memahami kebudayaan berarti mengeksplorasi bagaimana makna yang dihasilkan secara simbolis melalui praktek-praktek pemaknaan bahasa.

\section{Istilah Kekerabatan.}

Istilah kekerabatan erat sangkut pautnya dengan sistem kekerabatan hingga Burling (1970) membagi istilah kekerabatan dalam hubungan darah (konsaguinal) dan hubungan karena pernikahan (afinal). Hubungan darah (konsaguinal) yaitu saudara kandung laki-laki atau perempuan ego (keluarga inti) dan untuk hubungan pernikahan (afinal) sejajar ego, di bawah ego dan diatas ego, termasuk saudara tiri ego laki-laki dan saudara tiri perempuan. Istilah kekerabatan erat sangkut pautnya dengan sistem kekerabatan hingga Burling (1970) membagi istilah kekerabatan dalam hubungan darah (konsaguinal) dan hubungan karena pernikahan (afinal). Hubungan darah (konsaguinal) yaitu saudara kandung laki-laki atau perempuan ego (keluarga inti) dan untuk hubungan pernikahan (afinal) sejajar ego, di bawah ego dan diatas ego, termasuk saudara tiri ego laki-laki dan saudara tiri perempuan.

\section{Makna Budaya}

Spradley (1979) mengungkapkan bahwa untuk menemukan makna budaya dalam masyarakat, ada dua macam komponen yang harus dianalisis (1). Prinsip kegunaan, dalam analisis kegunaan makna symbol dapat ditemukan dengan menanyakan bagaimana symbol itu digunakan dan bukan menanyakan maknanya, symbol-simbol yang dimaksud antara lain kata, istilah, warna, gerak-gerik, tindakan dan segala aktifitas yang berhubungan dengan situasi yang satu dengan situasi yang lain. (2) Prinsip kognitif yakni segala sesuatu 
yang benar-benar terjadi, kemudian prinsip ini merupakan asumsi umum mengenai pengetahuan masyarakat setempat dalam kaitanya dengan makna budaya.

\section{Metodologi Penelitian}

Penelitian ini menggunakan pendekatan linguistik antropologi dengan metode kualitatif yang bersifat pendekatan deskriptif dengan tujuan untuk menggambarkan secara sistematik dan akurat tentang fakta dan karakteristik suatu populasi atau bidang tertentu. Metode pengumpulan data dalam penelitian ini yaitu : cakap (wawancara), disertai juga dengan teknik rekam dan catat. Data penelitian ini berupa kata dan frasa yang terdapat pada istilah kekerabatan yang dikemukakan penutur masyarakat Sangihe. Pada hakikatnya, informan atau narasumber merupakan alat pemerolehan data . Dengan demikian dekatan deskriptif diartikan sebagai prosedur pemecahan masalah dengan mengabarkan atau melukiskan keadaan subjek atau objek penelitian pada saat sekarang berdasarkan faktafakta yang tampak.

Dalam mengungkap istilah kekerabatan bahasa Sangihe, peneliti meggunakan metode kualitatif yaitu peneliti berusaha mendeskripsikan subjek penelitian,cara mereka berkata-kata dan memahami sikap atau prilaku dan ungkapan yang digunakan. Dari data yang terkumpul peneliti kemudian melakukan kegiatan peganalisisan data Tahap-tahap penganalisis data antara lain :

1. Mengidentifikasi istilah kekerabatan bahasa Sangihe menurut Burling (1970)

2. Menganalisis data berupa makna yang dihasilkan oleh masyarakat pendukung kebudayaan tersebut yang tercermin lewat bahasa yang di gunakan termasuk yang ada kaitannya dengan istilah kekerabatan dengan menggunakan teori Spredley (1979) dan Casson (1981), kita dapat memperoleh penelusuran tentang makna budaya dalam ungkapan bahasa dari informan.

\section{Hasil dan Pembahasan}

\section{Istilah Kekerabatan Konsaguinal dan Afinal}

Istilah kekerabatan konsaguinal adalah istilah kekerabatan yang mengacu pada sanak keluarga dekat atau hubungan pertalian darah dengan ego. Hubungan kekerabatan 
didasarkan pada garis keturunan pria maupun garis keturunan wanita, kemudian prinsip kekerabatan yang dipakai oleh masyarakat Sangihe, baik dari garis keturunan ayah maupun garis keturunan ibu, dengan menggunakan hubungan sedarah dan hubungan kekerabatan perkawinan. Pada Masyarakat Sangihe hubungan kekerabatan prinsip-prinsip bilatral yang ditentukan berdasarkan garis keturunan pria dan wanita serta kedudukan atau posisi, penghargaan, sopan santun kekeluargaan sehingga dapat ditentukan makna budayanya. Seperti dikemukakan oleh Spradley (1979) mengungkapkan bahwa untuk menemukan makna budaya dalam masyarakat, ada dua macam komponen yang harus dianalisis (1). Prinsip kegunaan, dalam analisis kegunaan makna simbol dapat ditemukan dengan menanyakan bagaimana simbol itu digunakan dan bukan menanyakan maknanya, simbol-simbol yang dimaksud antara lain kata, istilah, warna, gerak-gerik, tindakan dan segala aktifitas yang berhubungan dengan situasi yang satu dengan situasi yang lain. (2) Prinsip kognitif yakni segala sesuatu yang benar-benar terjadi, kemudian prinsip ini merupakan asumsi umum mengenai pengetahuan masyarakat setempat dalam kaitanya dengan makna budaya, demikian juga menurut Casson (1981) bahwa budaya adalah pola pikir yang ditentukan oleh bahasa memberikan petunjuk untuk pemahaman dalam bahasa tersirat makna-makna budaya yang mencakup berbagai aspek budaya.

Istilah kekerabatan yang berhubungan dengan ego, baik berdasarkan hubungan darah maupun hubungan kekerabatan karena perkawinan, seperti dijelaskan di bawah ini, disertai dengan tanda dan bagan pada lampiran.

\section{a. Istilah Akang}

Istilah yang diungkapkan untuk kakak laki-laki atau kakak perempuan ego, juga untuk sebutan pada anak pertama, baik pada laki-laki maupun perempuan, digunakan juga untuk panggilan sehari-hari dalam percakapan pada masyarakat Sangihe. Akang mempunyai tanggung jawab menyayangi dan melindungi terhadap adik-adiknya dalam berbagai macam persoalan yang ada di rumah termasuk membantu mengurus adik-adik, memandikan, memasak makanan membantu ibu atau membantu ayah melaut atau ladang. Menurut masyarakat pemakai bahasa Sangihe peran Akang ini sangat besar karena ketika dewasa nanti sebagai penganti orang tua, peran ini telah diajarkan sejak kecil ketika adikadiknya lahir dan saat orang tua meninggal maka peran Akang akan menggantikan peran 
orang tua sebagai yang mengayomi, melindungi serta menjadi penengah dalam segala keputusan saudara-saudaranya.

\section{b. Istilah Ara}

Istilah yang diungkapkan untuk kakak/adik laki-laki atau kakak perempuan ego yang berada pada posisi anak ke dua, baik pada laki-laki maupun perempuan, digunakan juga untuk panggilan sehari-hari pada masyarakat Sangihe. Tanggung jawab Ara dalam keluarga sama seperti Akang mengurus adik-adik, memandikan, memasak makanan membantu ibu atau membantu ayah melaut atau di ladang.

c. Istilah Ari

Istilah yang diungkapkan untuk kakak/adik laki-laki atau kakak perempuan ego yang berada pada posisi anak ketiga atau di tengah, juga untuk sebutan pada anak ke tiga atau di tengah, baik pada laki-laki maupun perempuan. Digunakan juga untuk panggilan sehari-hari dalam percakapan. Tangggung jawab Ari dalam keluarga sama halnya dengan Akang dan Ara mengurus adik-adik, memandikan, memasak makanan membantu ibu atau membantu ayah melaut atau di ladang, digunakan juga untuk panggilan sehari-hari dalam percakapan pada masyarakat Sangihe.

d. Istilah embo'

Istilah yang diungkapkan untuk adik laki-laki atau kakak perempuan ego juga untuk sebutan pada anak yang paling bungsu, baik pada laki-laki maupun perempuan. Digunakan juga untuk panggilan sehari-hari dalam percakapan pada masyarakat Sangihe. Tangggung jawab embo' dalam keluarga tidak seperti kakak-kakaknya yang melakukan semua pekerjaan di dalama rumah, embo' hanya mengikuti dan mendengarkan perintah yang disampaikan orang tua dan kakak-kakak dan dalam keluarga hanya dilindungi, disayang, diajarkan hal-hal kebaikan bagi kehidupannya kelak oleh orang tua dan kakakkakak. Jika dimintakan membantu ayah, ibu dan kakak-kakak maka embo' juga siap membantu.

e. Istilah Mbau 
Istilah Mbau diungkapkan untuk anak tunggal, Mbau bermakna harafiah satu atau satu-satunya. Pada Masyarakat penutur Sangihe memberikan sebutan tersendiri untuk anak tunggal yaitu Mbau, bisa jadi akan mewarisi harta milik orang tuanya.

\section{f. Istilah Amang}

Istilah Amang yang digunakan ego terhadap Amang atau ayah dalam keluarga, Amang mempunyai tanggung jawab penuh terhadap keluarga dalam kehidupan mereka sehari-hari berupa jasmania atau rohania. Menurut masyarakat pemakai bahasa Sangihe, selain harus mencari nafkah menjadi nelayan atau di ladang hingga menjadi keahlian khusus, Amang juga berperan mendidik, mengayomi dan melindungi keluarga serta menjadi teladan yang memberikan contoh bagi keluarga, baik hubungan darah maupun hubungan perkawinan, dalam masyarakat juga Amang menjadi contoh dan teladan. Untuk harta warisan Amang mempunyai hak penuh membagikan kepada anak-anak dalam keluarga, Amang memberikan pendapat dan masukan dari istri dan anak-anak dalam pembangiannya.

\section{f. Istilah Mahuaneng}

Istilah Mahuaneng yang digunakan ego terhadap kakak atau adik laki-laki dari ibu atau ayah ego. Mahuaneng yang berarti laki-laki

\section{e. Istilah Ninaung}

Istilah Ninaung ialah istilah yang disampaikan ego terhadap Ninaung yang telah melahirkan ego. Ninaung menurut masyarakat penutur budaya Sangihe sebagai seorang wanita yang bertanggung jawab dan mempunyai peran yang sangat besar dalam keluarga dalam hal membantu suami untuk menyelesaikan pekerjaan di dalam rumah yang dibutuhkan oleh anak-anak, peran Ninaung menjaga rahasia pribadi keluarga, melayani suami baik lahir dan batin serta menjaga, mendidik, mengasuh, membesarkan serta mengawasi perilaku anak-anak mereka dengan menanamkan kepada mereka berbagai perilaku terpuji serta tujuan-tujuan mulia yang dapat menjaga kenyamanan keluarga serta dapat mengatur keadaan rumah, sehingga dapat memberikan suasana menyenangkan dan seluruh anggota keluarga merasa terpikat. Bagi Masyarakat penutur bahasa Sangihe, Ninaung mempunyai perasaan yang lemah lembut terhadap suami dan anak-anak, keluarga 
sedarah ataupun hubungan karna perkawinan. Peran dan tanggung jawab Ninaung inilah yang dijadikan contoh bagi anak-anak mereka nanti.

\section{g. Istilah I'wawu}

Istilah I'wawu secara harafiah terdiri dari dua morfem yakni morfem ' $I$ ' bermakna 'saya' dan morfem ' 'wawu' yang dituakan 'Istilah ini dipakai ego kepada ibu dari ibu ego yang merupakan kesepakatan masyrakat penutur Sangihe sebagai seorang yang sangat penting dalam keluarga, dalam pekerjaan sehari-hari I'wawu dapat mengantikan pekerjaan ibu ego jika sedang bekerja. I'wawu juga dianggap sebagai seorang yang dianggap mempunyai kelebihan yang ada pada keluarga sedarah karna dituakan bahkan di tengahtengah masyarakat karna mampu mendoakan dalam hal baik yang terjadi di dalam keluarga dalam bentuk berupa nasehat, motivasi, dorongan yang berhubungan dengan kehidupan.

\section{e. Istilah I'tuang}

Istilah I'tuang terdiri dari dua morfem yaitu morfem ' $I$ ' yang berarti saya dan morfem 'tuang' yang berarti yang paling dituakan. Istilah ini merupakan kesepakatan masyrakat penutur Sangihe sebagai seorang yang sangat penting dalam keluarga, dalam pekerjaan sehari-hari I'tuang dapat mengantikan pekerjaan ibu dari ibu ego jika sedang bekerja. I'tuang juga dianggap sebagai seorang yang dianggap mempunyai kelebihan yang ada pada keluarga sedarah karna sangat dituakan bahkan di tengah-tengah masyarakat karna mampu mendoakan dalam hal baik yang terjadi di dalam keluarga dalam bentuk berupa nasehat, motivasi, dorongan yang berhubungan dengan kehidupan.

h. Istilah Tete

Istilah Tete ialah istilah yang ditujukan ego terhadap ayah dari ayah ego, dalam masyarakat penutur Sangihe Tete memiliki peranan di dalam keluarganya dianggap penting bahkan Tete dianggap seseorang yang mempunyai kelebihan dalam keluarga sedarah dan sangat disegani serta dihormati di dalam keluarga maupun di luar keluarga karna dapat memberikan nasehat, motifasi, dorongan yang berhubungan dengan kehidupan.

\section{i. Istilah Yupung}

Istilah Yupung merupakan istilah dalam masyarakat Sangihe sebagai seorang yang peranan di dalam keluarganya dianggap penting bahkan dalam berbagai hal. Bahkan Yupung dianggapa sebagai orang yang mempunyai kelebihan yang sangat besar yang ada 
pada keluarga sedarah karna dianggap seseorang yang sangat dituakan dalam perilaku sehari-hari ditengah-tengah keluarga maupun masyarakat karna mampu mendoakan sesuatu yang baik yang terjadi di dalam keluarga, maupun diluar keluarga dalam bentuk memberikan nasehat, motifasi, dorongan yang berhubungan dengan kehidupan yang baik.

\section{j. Istilah Mandehokang}

Istilah Mandehokang merupakan istilah untuk pasangan suami istri, baik istri kepada suami atau suami kepada istri. Mandehokang mempunyai makna yang kuat dimana hubungan batin antara pasangan untuk membangun rumah tangga dengan dasar tanggung jawab dari peran masing-masing pasangan suami dan istri. Tanggung jawab tersebut berupa jasmani maupun rohani, mendidik, membina dan membesarkan anak-anak serta saling menjaga keharmonisan suami istri sehingga proses tugas rumah tangga berjalan dengan baik. Selain menjaga keharmonisan sebagai pasangan suami istri, juga menjaga keharmonisan dalam keluarga lainya baik hubungan darah maupun hubungan perkawinan.

k. Istilah Ipage

Istilah Ipage ialah istilah yang digunakan suami istri terhadap adik atau kakak lakilaki atau perempuan. Ipage dianggap sebagai orang yang mampu memberikan dukungan kepada saudara sedarah yang dinikahinya. Istilah Ipage terdiri dari dua morfem ' $I$ ' yang berarti kepunyaan saya 'page' ipar adalah istilah sopan untuk menghormati dan menghargai seperti adik dan kakak dalam membagi pengalaman dan pangdangan hidup sehari-hari dan tetap menjaga keharmonisan ikatan keluarga karna ikatan perkawinan.

\section{K. Istilah Tarahuwe}

Istilah Tarahuwe ialah istilah yang digunakan suami istri terhadap sesame ipar adalah istilah sopan untuk menghormati dan menghargai istri atau suami dari kakak atau adik dan merasa menjadi seperti adik dan kakak dalam membagi pengalaman dan pangdangan hidup sehari-hari dan tetap menjaga keharmonisan ikatan keluarga karna ikatan perkawinan.

\section{Istilah Gagurang kinaratinang}

Istilah Gagurang kinaratinang, berasal dari orang tua mantu laki-laki, kata yang berasal dari dua kata Gagurang yang berarti orang tua laki-laki dan kata kinaratinang 
yang berarti anak dari menantu . Dalam masyarakat Sangihe bagi baik laki-laki maupun perempuan ungkapan Gagurang kinaratinang jarang menggunakan istilah tersebut jadi tergantung ungkapan yang yang digunakan tentunya disesuaikan dengan keluarga yang dikawininya. Dalam keluarga sudah dianggap menjadi keluarga sedarah.

\section{m. Istilah Bawine Kinaratinang}

Istilah Bawine Kinaratinang bermakna orang tua mantu, berasal dari dua yaitu kata yang berasal dari kata Bawine yang berarti perempuan atau orang tua dan Kinaratinang yang berarti anak dari menantu . Dalam masyarakat Sangihe bagi baik laki-laki maupun perempuan ungkapan Bawine Kinaratinang jarang menggunakan istilah tersebut jadi tergantung ungkapan yang yang digunakan tentunya disesuaikan dengan keluarga yang dikawininya. Dalam keluarga sudah dianggap menjadi keluarga sedarah.

\section{Simpulan}

Setelah melalui proses tahap demi tahap dalam penelitian dan pembahasan masalah yang telah diuraikan pada bab sebelumnya, maka dapat diperoleh kesimpulan sebagai berikut:

1. Masyarakat penutur bahasa Sangihe mengenal serta menggunakan istilah kekerabatan berdasarkan hubungan darah (Konsaguinal) dan hubungan kekerabatan atau perkawinan (Afinal). Istilah kekerabatan yang tepat harus digunakan oleh ego, sesuai dengan adat yang berlaku karena prinsip rasa hormat dan sopan. Pada bahasa Sangihe hanya mengenal istilah kekerabatan sampai tiga generasi, di atas ego maupun di bawah ego . Pada permasalahan pertama hasil dan pembahasan penelitian menunjukkan kesamaan dengan teori Burling (1970) yang membagi istilah kekerabatan kedalam dua betuk yaitu istilah kekerabatan Konsaguinal dan Afinal. kekerabatan Konsaguinal berdasarkan hubungan darah atau leuarga inti yang dekat, istilah kekerabatan Afinal sejajar ego, di atas ego dan di bawah ego.

2. Istilah kekerabatan pada masyarakat Sangihe dibagi berdasarkan usia lebih tua, lebih muda dan sebaya, sesuai dengan siapa yang berbiara, siapa yang yang 
diajak bicara dalam situasi dan waktu pembicaraan yang di dalamnya menggunakan makna budaya penghormatan, sopan dantun dan kepercayaan, hal ini sejalan dengan teori Spradley (1979) mengungkapkan bahwa untuk menemukan makna budaya dalam masyarakat, ada dua macam komponen yang harus dianalisis (1). Prinsip kegunaan, dalam analisis kegunaan makna simbol dapat ditemukan dengan menanyakan bagaimana simbol itu digunakan dan bukan menanyakan maknanya, simbol-simbol yang dimaksud antara lain kata, istilah, warna, gerak-gerik, tindakan dan segala aktifitas yang berhubungan dengan situasi yang satu dengan situasi yang lain. (2) Prinsip kognitif yakni segala sesuatu yang benar-benar terjadi, kemudian prinsip ini merupakan asumsi umum mengenai pengetahuan masyarakat setempat dalam kaitanya dengan makna budaya dan menurut Casson (1981) bahwa budaya adalah pola pikir yang ditentukan oleh bahasa memberikan petunjuk untuk pemahaman dalam bahasa tersirat makna-makna budaya yang mencakup berbagai aspek budaya, sehingga penelitian ini merupakan penguatan teori.

\section{Daftar Pustaka}

Alwasilah, A.Chaedar.1993.Linguistik Suatu Pengantar. Jakarta: Penerbit Angkasa Bandung

Aminuddin , 1988. Semantik: Pengantar Studi tentang Makna, Bandung : Sinar baru Balai Pustaka, 2002. Kamus Besar Bahasa Indonesia. Jakarta

Ba'dulu A.M. dan Herman. 2005 Morfosintaksis, Rineka Cipta, Jakarta

Badudu, Yus. 1983. Membina Bahasa Indonesia Baku,Pustaka Prima, Bandung

Bawole, 1981 dalam Prof. A.B.G.Ratu - Bahasa di Minahasa,Profil Kebudayaan Minahasa Bungin, B. 2007. Penelitian Kualitatif. Jakarta: Prenada Media Grup.

Chaer,A.1990. Pengantar Semantik Bahasa Indonesia. Jakarta: Rineka Cipta

Chaer,A.1989. Penggunaan Imbuhan Bahasa Indonesia. Jakarta: Rineka Cipta

Chaer dan Agustina. 2004. Sosiolinguistik Perkenalan Awal. Jakarta: Rineka Cipta.

Casson, R. W. 1989. Languange, Culture, and Cognition. New York, Macmilan Publishing Co. New York

Cook, Wolter A.1969. Introdution to Tagmamic Analysis, London :Holt,Rinhart and Winston.

Decroly Juda,S.Pd, Tata Bahasa Sangihe.

Djajasudarma, T.F. 1997. Nilai Budaya dalam Ungkapan dan Pribahasa Sunda, Pusat pembunaan dan Pengembangan Bahasa, Depdikbud, Jakarta

Djojosuroto, K. 2007. Filsafat Bahasa. Yogyakarta: Pustaka Book Publisher.

Duranti, A. 1997. Linguistic Antropology. Camridge : Cambridge University Press 
Endraswara, S. 2009. Metodologi penelitian Folklor. Konsep, Teori, dan Aplikasi. MedPress, Yogyakarta.

Foley, William A. 1997. Antrophological Linguistics; An introduction. Oxford: Blackwell Publisher.

'Fox, Robin. 1967. Kinship and marriage an anthropological perspective. The Press Syndicate university of Cambridge Publisher

Kartomiharjo, S. 1988. Bahasa Sebagai Cerminan Kehidupan Masyarakat. Jakarta: Dikbud

Karouw, S. 2011. Sistem Kekerabatan Bahasa Tobelo.Tesis. Manado: Universitas Sam Ratulangi

Koentjaranigrat. 1990. Beberapa Pokok Antropologi Sosial. Jakarta: Penerbit Dian Rakyat. Kridalaksana, Harimurti. 2008. Kamus Linguistik. Jakarta: PT Gramedia

Kridalaksana, Harimurti. 2001. Kamus Linguistik. Jakarta: PT Gramedia

Kuper, A. dan Jessica, K. 2000. Ensiklopedi Ilmu-ilmu Sosial. Diterjemahkan oleh H. Munandar, et al. Cetakan I. Jakarta: Raja Grafindo Persada.

Kuswarno, E. 2008. Etnografi Komunikasi Suatu Pengantar dan Contoh Penelitian. Widya Padjajaran.

Leech, G. 1974. Semantik. Yogyakarta: Pustaka Pelajar Offset.

Makasar, S. 2012. Sasahara. Manado: Penerbit Obor Pelita.

Mamita, R dan Oktavianus, 2008 Perilaku Berbahasa Masyarakat Minangkabau dan Pengaruhnya Terhasap Pemakaian Ungkapan Sebagai Media Pendidikan Informal Keluarga. Linguistik Indonesia. Jurnal Imiah MLI, Jakarta No.2 Tahun ke 26.

Mulyanto. 2009. Kajian Etnolinguistik: Ungkapan Salam Tradisional Jawa dan Pola Pikir Masyarakatnya. Kawanua Jurnal Ilmiah Bahasa dan Sastra. Departemen Pendidikan Nasional Pusat Bahasa Balai Bahasa Sulawesi Utara.

Nebath,Paul dkk.1985. Sastra Lisan Sangir Talaud. Pusat Pembinaan dan Pengembangan Bahasa Departemen Kebudayaan : Jakarta

Nida, E.A .1970. Morphology. The Descriptive Analysis of Words. The University of Michigan Press.

O’Grandy, William dan Michael Dobrovsky. 1989. Contemporary Linguistics, New York: St. Martin Press

Parera, JD. 2004. Teori Semantik edisi kedua. Jakarta : Penerbit Erlangga.

Ratna, K. Nyoman. 2009. Stilistika Kajian Puitika Bahasa,Sastra dan Budaya. Yogyakarta: Pustaka Pejar.

Richards, J.C and Richard, S 2002 Logman Digtionary of applied Linguistics. Third Edition. Logman Group UK Limited,Inggris.

Saeed, J. 2001. Semantic. Blackwell Publisher Ltd, Massachusetts

Santoso, A. 2006. Bahasa, Masyarakat, dan Kuasa: Topik-Topik Kritis dalam Kajian Ilmu Bahasa. Malang: Jurusan Sastra Indonesia, Fakultas Sastra, Universitas Negeri Malang.

Saussure, Ferdinand De. 1993. Pengantar Linguistik Umum Terjemahan Rahayu S. Hidayat. Yogyakarta: Gadjah Mada University Press.

Sendjaja, S. Djuarsa. 1994. Teori komunikasi. Jakarta: Universitas Terbuka

Simatupang, Maurits D.S. 2000. Pengantar Teori Terjemahan. Jakarta: DirjenDikti Depdiknas. 
Spradley, J.P. 1979. The Etnographic Interview. Holt, Rinehart and Wilson. USA.

Storey, J. 1993. Teori Budaya dun Budaya Pop. Memetakan Lanskap Konseptual Cultural Studies. Terjemahan Dede Nurdin (2003). Yogyakarta: Qalarn

Sudaryanto, 1993. Metode dan Aneka Teknis Analisis Bahasa. Pengantar Penelitian Wahana Kebudayaan secara Linguistik. Duta Wacana Universitas Press. Yogyakarta. 